\title{
DOSE-DEPENDENT EFFECTS OF GAMMA IRRADIATION ON COLLAGEN IN VEGETABLE TANNED LEATHER BY MOBILE NMR SPECTROSCOPY
}

\section{STUDIUL EFECTULUI DOZEI DE RADIATII GAMMA ASUPRA COLAGENULUI DIN PIELEA TĂBĂCITĂ VEGETAL UTILIZÂND SPECTROSCOPIA RMN}

\author{
Claudiu ŞENDREA ${ }^{1,2^{*}}$, Elena BADEA ${ }^{1,3}$, Ioana STĂNCULESCU ${ }^{4,5}$, Lucreţia MIU $^{1}$, Horia IOVU² \\ ${ }^{1}$ National Research and Development Institute for Textile and Leather (INCDTP), ICPI Division, Ion Minulescu 93, 031215 Bucharest, Romania \\ ${ }^{2}$ Faculty of Applied Chemistry and Materials Science, University Politehnica of Bucharest, 1-7 Polizu Str., 011061 Bucharest, Romania
}

${ }^{3}$ Department of Chemistry, Faculty of Mathematics and Natural Sciences, University of Craiova, 107 Calea Bucuresti, 200512 Craiova, Romania

${ }^{4}$ Horia Hulubei National Institute for Physics and Nuclear Engineering (HH-IFIN), Radiation Processing Center, Magurele, Romania

${ }^{5}$ University of Bucharest, Department of Physical Chemistry, 4-12 Regina Elisabeta Av., Bucharest, Romania

\begin{abstract}
DOSE-DEPENDENT EFFECTS OF GAMMA IRRADIATION ON COLLAGEN IN VEGETABLE TANNED LEATHER BY MOBILE NMR SPECTROSCOPY
ABSTRACT. The dose dependent effect of gamma irradiation on collagen in vegetable tanned leather was studied by unilateral nuclear magnetic resonance (NMR). Examination of the irradiated samples after 1 week of treatment revealed variations of both spin-lattice $\left(T_{1}\right)$ and spin-spin $\left(T_{2}\right)$ proton relaxation times. To evaluate the long-term effects of gamma irradiation, the irradiated samples were further exposed to accelerated ageing at $40^{\circ} \mathrm{C}$ and weekly alternate $30 \%$ and $75 \%$ relative humidity (RH) for 12 weeks. The synergistic action of temperature and relative humidity caused distinct variations of both $T_{1}$ and $T_{2}$ relaxation times suggesting distinct modifications within the collagen fibril structure. Structural variations were attributed to cross-linking, the prevalent pattern at $25 \mathrm{kGy}$ dose, while polypeptide chain scission was shown to be prevailing at higher doses.
\end{abstract}

KEY WORDS: collagen, vegetable tanned leather, gamma irradiation, unilateral NMR

STUDIUL EFECTULUI DOZEI DE RADIATII GAMMA ASUPRA COLAGENULUI DIN PIELEA TĂBĂCITĂ VEGETAL UTILIZÂND SPECTROSCOPIA RMN

REZUMAT. S-a studiat efectul dozei de iradiere gamma asupra colagenului din pielea tăbăcită vegetal prin rezonanţă magnetică nucleară unilaterală (RMN). Examinarea probelor iradiate după 1 săptămână de tratament a indicat variaţii atât ale timpilor de relaxare a protonilor spin-reţea $\left(T_{1}\right)$, cât şi a celor spin-spin $\left(T_{2}\right)$. Pentru a evalua efectele pe termen lung ale iradierii gamma, probele iradiate au fost expuse în continuare la îmbătrânire accelerată la $40^{\circ} \mathrm{C}$ şi s-a alternat săptămânal umiditatea relativă (UR) în intervalul 30\%-75\% timp de 12 săptămâni. Acçiunea sinergică a temperaturii şi umidităţii relative a produs modificări distincte ale timpilor de relaxare $T_{1}$ şi $T_{2}$, sugerând modificări distincte în structura fibrilelor de colagen. Până la doze de 25 kGy mecanismul predominant a fost reticularea, în timp ce la doze mai mari a predominat scindarea lanţului polipeptidic.

CUVINTE CHEIE: colagen, piele tăbăcită vegetal, iradiere gamma, RMN unilaterală

L'EFFET DE L'IRRADIATION GAMMA SUR LE COLLAGÈNE DU CUIR À TANNAGE VÉGÉTAL EN UTILISANT LA SPECTROSCOPIE RMN

RÉSUMÉ. On a étudié l'effet de la dose d'irradiation gamma sur le collagène du cuir à tannage végétal par la résonance magnétique nucléaire unilatérale (RMN). L'analyse des échantillons irradiés après 1 semaine de traitement a montré des variations des temps de relaxation des protons spin-réseau $\left(T_{1}\right)$ et spin-spin $\left(T_{2}\right)$. Pour évaluer les effets à long terme de l'irradiation gamma, les échantillons irradiés ont été davantage exposés à un vieillissement accéléré à $40^{\circ} \mathrm{C}$ et on a modifié chaque semaine l'humidité relative (HR) entre $30 \%$ à $75 \%$ pendant 12 semaines. L'action synergique de la température et l'humidité relative ont produit des changements distincts dans les temps de relaxation $T_{1}$ et $T_{2}$, ce qui suggère des changements distincts dans la structure des fibrilles de collagène. À la dose de $25 \mathrm{kGy}$ le mécanisme prédominant était la réticulation, tandis qu'aux doses plus élevées le clivage de la chaîne polypeptidique a été prédominant.

MOTS-CLÉS: collagène, cuir tanné végétal, irradiation gamma, RMN unilatérale

\section{INTRODUCTION}

Historical and archaeological leather objects, and artefacts are an infinite source of information of historical and cultural interest; they represent repositories of tangible-intangible cultural heritage

\section{INTRODUCERE}

Obiectele istorice şi arheologice, precum şi artefactele din piele sunt o sursă infinită de informaţii de interes istoric şi cultural; acestea reprezintă depozite inestimabile de valori culturale tangibile si

* Correspondence to: Claudiu ŞENDREA, INCDTP - Division: Leather and Footwear Research Institute, 93 Ion Minulescu, sector 3 , 031215 Bucharest, e-mail: claudiusendrea@yahoo.com 
and illustrate the evolution of social customs, habits, aesthetics and technology, but also the perpetuation of popular and religious traditions. It is vital therefore that these materials and artefacts remain well preserved.

Old leather is a biomaterial composed of animal hides that have been chemically treated mainly by tanning to increase chemical and physical durability over time and confer desired handling and working characteristics. The tanning procedure permanently alters the chemical structure of the collagen. The tannin molecules stabilise the collagen matrix by linking to the amino acid chains via hydrogen and/or covalent bonding, depending on the tannin type [1]. The oldest system of tanning relies on the chemical action of vegetable extracts containing tannins, while tanning with chromium salts was introduced at the end of the $19^{\text {th }}$ century. The vegetable tannins are natural polyphenols; the chemical structure of this group of compounds was described by HPLCESI-MS/MS method [2]. Tannins act by displacing the hydrogen bonded water on the collagen molecule and consolidating the collagen fibre network of the dermis. By taking up most of the available hydrogen bonding sites of collagen, the tannins promote dehydration and consequently cross-linking, resulting in a material more stable against temperature changes, water resistant, and much more durable than the raw animal hide. However, natural polymers such as collagen are intrinsically degradable. Biodegradation is due to insects and microorganisms like bacteria or fungi for which collagen is an excellent nutrient. Water, oxygen, polluting gases from the atmosphere, acids (e.g. from soil in the case of buried objects or those produced into the leather during its ageing), temperature, and light are aggressive agents inducing structural modification by converting collagen into gelatin and causing polypeptide chain scission. Not rarely biological, physical and chemical deterioration factors synergistically act and accelerate the degradation kinetics. In fact, the variety of biodeterioration phenomena observed on collagen materials of cultural heritage is determined intangibile, ilustrând evoluţia cutumelor sociale, a obiceiurilor, esteticii şi tehnologiei, dar şi perpetuarea tradiţiilor populare şi religioase. Prin urmare, este esenţial ca aceste materiale şi obiecte să fie bine conservate şi transmise generaţiilor viitoare.

Pielea veche este un biomaterial realizat din piei de origine animală care au fost tratate chimic, în principal prin tăbăcire, pentru a le creşte durabilitatea chimică şi fizică în timp şi pentru a le conferi proprietăţile tactile şi caracteristicile de folosinţă dorite. Procesul de tăbăcire modifică permanent structura chimică a colagenului. Moleculele taninului stabilizează matricea de colagen prin legarea la lanţurile de aminoacizi prin legături de hidrogen şi/sau covalente, în funcţie de tipul de tanin [1]. Unul dintre cele mai vechi sisteme de tăbăcire se bazează pe aç̧iunea chimică a extractelor vegetale care conţin taninuri, în timp ce tăbăcirea cu săruri de crom a fost introdusă ca procedeu de prelucrare a pieilor la sfârşitul secolului al XIX-lea. Taninurile vegetale sunt polifenoli naturali; structura chimică a acestei grupe de compuşi poate fi identificată prin metoda HPLC-ESI-MS/MS [2]. Taninul acţionează prin deplasarea apei legate prin legături de hidrogen de molecula de colagen şi prin consolidarea reţelei de fibre de colagen din dermă. Prin ocuparea celor mai multe poziţii disponibile pentru legăturile de hidrogen, tăbăcirea facilitează deshidratarea şi în consecinţă reticularea colagenului, având ca rezultat un material mai stabil la schimbările de temperatură, rezistent la apă şi la acţiunea microorganismelor deci mult mai durabil decât pielea brută. Cu toate acestea, polimerii naturali precum colagenul sunt materiale supuse proceselor de biodegradare. Biodegradarea se datorează insectelor şi microorganismelor cum ar fi bacteriile sau fungii. Pentru acestea, colagenul este un nutrient excelent. Apa, oxigenul, gazele poluante din atmosferă, acizii (de exemplu, acizii din sol în cazul obiectelor îngropate, sau cei produşi în piele în timpul îmbătrânirii), temperatura şi lumina sunt agenţi agresivi care induc modificări structurale prin transformarea colagenului în gelatină şi care provoacă scindarea lanţurilor polipeptidice. Nu rareori factorii de deteriorare biologică şi fizico-chimică acţionează sinergic accelerând viteza de degradare. De fapt, varietatea fenomenelor de biodegradare observate 
by several factors, such as the chemical composition and nature of the material itself, the climate and exposure of the object, in addition to the manner and frequency of surface cleaning and housekeeping in museums, archives and libraries. The degradation of leather, which is mainly composed of collagen, is in fact a complex process, which involves the chemical oxidative deterioration of amino acid chains and hydrolytic cleavage of the peptide structure.

Different methods against biodeterioration have been established and used, especially those based on antifungal and antibacterial products, either synthetic or natural, as well as on anoxic treatments and fumigation with gases (e.g. ethylene oxide). Recently, due to a number of advantages, gamma irradiation was taken in consideration as a low-cost method for mass disinfestations and conservation purposes. For example, gamma irradiation treatment associates no risk for the operator, restorer, curator, visitor, or environment; no toxic or radioactive residues remain in the treated item; excellent efficiency is extended to the whole inner volume based on the excellent penetration of gamma radiation; large amounts of objects can be treated simultaneously in a short time [3]. This treatment, however, may affect the structural and mechanical properties of materials because the dose required to annihilate the microorganisms is rather high. Therefore, a systematic research is needed to investigate the effects of gamma irradiation on collagen materials.

The present investigation has been undertaken with the object of obtaining new information on the effect of gamma irradiation on collagen in vegetable tanned leather. Such information, besides being of theoretical interest, is of practical importance with respect to the increasing use of ionizing radiation for the treatment of historical collagenous materials such as leather, parchment, bones and mummies. So far, only few studies concerning the effect of gamma irradiation on fibrillar collagen from bone and rattail tendon were reported [4-6]. Recently the la materialele colagenice din patrimoniul cultural este determinată de mai mulţi factori, cum ar fi compoziţia chimică şi natura materialului însuşi, microclimatul în care au fost depozitate şi/sau expuse, precum şi modul şi frecvenţa de curăţare superficială şi eventualele tratamente de conservare aplicate. Degradarea pielii, care este compusă în principal din colagen, este un proces complex, care implică deteriorarea oxidativă a lanţurilor de aminoacizi şi scindarea hidrolitică a structurii peptidice.

De-a lungul timpului au fost utilizate diferite mijloace de combatere a biodegradării, în special cele bazate pe utilizarea produselor antifungice şi antibacteriene, sintetice sau naturale, precum şi tratamentele anoxice şi de fumigaţie cu gaze (de exemplu, oxid de etilenă). Ca urmare a unei serii de avantaje, iradierea cu radiaţii gamma a fost recent reconsiderată, aceasta fiind o metodă necostisitoare, adecvată pentru decontaminarea în masă a colecţiilor. De exemplu, tratamentul prin iradiere gamma nu se asociază cu riscuri pentru operatori, restauratori, curatori, vizitatori sau pentru mediul înconjurător; nu produce reziduuri toxice sau radioactive în elementul tratat; tratamentul este eficient în întregul volum datorită capacităţii de penetrare a radiaţiilor gamma; cantităţi mari de obiecte pot fi tratate simultan; timpul de tratare este scurt [3]. Acest tratament poate însă afecta proprietăţile structurale ale materialelor, doza necesară pentru a anihila fungi, bacterii, larve, insecte fiind relativ ridicată. De aceea, este necesară o cercetare minuţioasă a efectelor iradierii cu radiaţii gamma asupra materialelor pe bază de colagen precum pielea şi pergamentul.

Rezultatele ce vor fi prezentate în această lucrare fac parte dintr-un studiu amplu al cărui scop constă în obţinerea de noi informaţii privind efectul radiaţiilor gamma asupra colagenului din pielea tăbăcită vegetal. Astfel de informaţii, pe lângă faptul că sunt de mare interes teoretic, au şi o importanţă practică în ceea ce priveşte utilizarea tot mai frecventă a radiaţiilor ionizante pentru decontaminarea materialelor colagenice istorice, cum ar fi pielea, pergamentul, oasele şi mumiile. Până în prezent, au fost raportate doar câteva studii privind efectul 
gamma irradiation effects on the colour and texture of parchment documents was reported and the maximum gamma radiation dose $\left(D_{\max }\right)$ that could guarantee parchment documents decontamination treatment, without significant alteration of their physical properties was estimated [7]. However, no studies on collagen in leather have yet been reported. The present work focused on the dose-dependent effect of gamma irradiation on collagen in leather obtained by tanning calf hides with condensed tannins (i.e. quebracho wood and mimosa bark commercial extracts). Moreover, the leather samples exposed to irradiation were then subjected to accelerated ageing to explore the long-term effect of gamma irradiation, too. Some of us have reported that denaturation of collagen induces modifications of the structure that can be followed by proton relaxation time determination [8, 9]. This paper presents both $T_{1}$ relaxation time, also called spinlattice, and $T_{2}$ spin-spin relaxation time measured by the unilateral Nuclear Magnetic Resonance (NMR) technique, to evaluate the dose dependences of structural changes occurring in collagen within short- and long-time periods after gamma irradiation treatment. For this purpose, the irradiated leather samples were exposed to accelerated ageing at $40^{\circ} \mathrm{C}$ and weekly alternate $30 \%$ and $75 \%$ relative humidity $(\mathrm{RH})$ for 12 weeks.

This is the very first time when unilateral NMR is applied to achieve a characterisation of the effect of gamma irradiation on molecular water-collagen interaction in vegetable tanned leather.

\section{EXPERIMENTAL}

\section{Materials}

New vegetable tanned leathers were prepared from calf hides with mimosa-bark and quebrachowood commercial extracts using a method based on a traditional recipe [10] developed at the National Research and Development Institute for Textile and iradierii cu radiaţii gamma asupra colagenului fibrilar din oase şi din tendon (din coadă de şobolan) [4-6]. Recent, s-au raportat efectele iradierii gamma asupra culorii şi texturii documentelor pe suport de pergament şi s-a estimat doza maximă de radiaţii gamma $\left(D_{\text {max }}\right)$, care să garanteze un tratament de decontaminare eficient fără alterarea semnificativă a proprietăţilor fizice ale documentelor [7]. Cu toate acestea, nu au fost încă raportate studii privind colagenul din pielea tăbăcită. În lucrarea de faţă s-a urmărit efectul dozei de radiaţii gamma asupra colagenului din piele de viţel tăbăcită cu taninuri condensate, şi anume extracte tanante comerciale de quebracho şi mimosa. Mai mult decât atât, probele de piele expuse la iradiere au fost apoi supuse la tratamente de îmbătrânire accelerată $\left(40^{\circ} \mathrm{C}\right.$, UR $30 \%$ şi $75 \%$, alternând săptămânal umiditatea relativă (UR) între 30\% şi 75\%, timp de 12 săptămâni) pentru a explora efectul pe termen lung al iradierii. Unii dintre autorii lucrării au arătat că denaturarea colagenului în pergament şi piele induce modificări ale structurii care pot fi relevate prin determinarea timpului de relaxare a protonilor apei legate din structura acestor materiale [8, 9]. Lucrarea de faţă prezintă variaţia valorilor timpului de relaxare spin-reţea, $T_{1}$, şi a timpului de relaxare spin-spin, $T_{2}$, măsuraţi prin tehnica de rezonanţă magnetică nucleară (RMN) unilaterală, în funcţie de doza de radiaţii gama aplicată şi de efectul tratamentului de îmbătrânire artificială.

Acesta este primul studiu bazat pe utilizarea tehnicii de RMN unilaterală în vederea caracterizării efectului radiaţiilor gamma asupra interacţiunii apă-colagen la nivel molecular în pielea tăbăcită vegetal.

\section{PARTEA EXPERIMENTALĂ}

\section{Materiale}

S-au realizat piei noi de viţel tăbăcite vegetal cu extracte comerciale de mimoză şi quebracho folosind o metodă bazată pe reţete tradiţionale [10] pusă la punct la Institutul Naţional de Cercetare şi Dezvoltare pentru Textile şi Pielărie, Sucursala ICPI, Bucureşti. Probele de 
Leather, ICPI Division, Bucharest. Quebracho and mimosa leather samples were exposed to ${ }^{60} \mathrm{Co}$ gamma rays at the IRASM Center for Technological Irradiations of the Horia Hulubei National Institute for Physics and Nuclear Engineering (HH-IFIN), Bucharest. IRASM facility is a category IV gamma irradiator. The radiation doses applied were 10, 25, 50 and $100 \mathrm{kGy}$ with a dose uniformity ratio (DUR) of 1.14. The quebracho leather samples were then used to evaluate the short-time effect of the irradiation treatment by measuring the proton relaxation times $T_{1}$ and $T_{2}$ after the treatment. The mimosa leather samples were further exposed to accelerated ageing by heating at $40^{\circ} \mathrm{C}$ in controlled atmosphere at weekly alternating $30 \%$ and $70 \% \mathrm{RH}$ for 12 weeks and used to evaluate the long-term effect of gamma irradiation. The artificially ageing treatments were carried out with a Binder APT Line KBF-ICH test chamber.

\section{Method}

Unilateral NMR measurements were performed using a cylindrical shape unilateral NMR-MOUSE bar magnet with a frequency of $20.05 \mathrm{MHz}$. The NMR -MOUSE ${ }^{\circledR}$ (Mobile Universal Surface Explorer) is a small portable, non-destructive, single-sided NMR device [11]. The MOUSE equipment was connected to a Bruker-Minispec spectrometer which works as an amplifier in the transmission of radio frequency (RF) pulses and as a preamplifier in reception. This system can measure proton relaxation times $T_{1}$ and $T_{2}$. The longitudinal relaxation time $T_{1}$, also called spin-lattice relaxation time, was measured using a saturation recovery sequence with an echo-time of about $25 \mathrm{~s}$. The spin-spin relaxation time $T_{\text {2eff }}$ was measured using a Carr-Purcell-Meiboom-Gill (CPMG) pulse sequence. The relaxation times were extracted from the experimental data with the help of exponential functions (Figure 1). piele tăbăcită cu extracte de quebracho şi mimoză au fost expuse razelor gamma ${ }^{60} \mathrm{Co}$ la Centrul de Iradieri Tehnologice IRASM din cadrul Institutului Naţional de Fizică şi Inginerie Nucleară Horia Hulubei (IFIN-HH), Bucureşti. Echipamentul din cadrul IRASM este un iradiator gamma de categoria IV. Dozele de radiaţii aplicate au fost de 10, 25, 50 şi 100 kGy, cu un raport al uniformităţii dozei (DUR) de 1,14. Probele de piele tăbăcită cu quebracho au fost apoi folosite pentru a evalua efectul pe termen scurt al tratamentului de iradiere prin măsurarea timpilor de relaxare a protonilor $T_{1}$ şi $T_{2}$ imediat după tratament. Probele de piele tăbăcită cu mimoză au fost expuse în continuare la îmbătrânire accelerată prin încălzire la $40^{\circ} \mathrm{C}$ în atmosferă controlată, alternându-se săptămânal UR între $30 \%$ şi $70 \%$, timp de 12 săptămâni şi utilizate pentru a evalua efectul pe termen lung al iradierii gamma. Tratamentele de îmbătrânire artificială au fost efectuate cu o cameră de testare Binder APT Line KBF-ICH.

\section{Metodă}

Experimentele au fost realizate cu ajutorul unui echipament NMR-MOUSE sub formă de magnet cilindric cu o frecvenţă de 20,05 MHz. NMR-MOUSE ${ }^{\circledR}$ (Mobile Universal Surface Explorer) este un dispozitiv mic, portabil, care permite analiza probelor şi a artefactelor in mod ne-invaziv şi nedistructiv [11]. Echipamentul NMR MOUSE a fost conectat la un spectrometru Bruker-Minispec (care funcţionează ca un amplificator la transmisia impulsurilor la frecvenţe radio (RF) şi ca un preamplificator la recepţie) pentru măsurarea timpilor de relaxare ai protonilor $T_{1}$ şi $T_{2}$. Timpul de relaxare longitudinal $T_{1}$, numit şi timp de relaxare spin-reţea, a fost măsurat folosind o secvenţă de recuperare a saturaţiei cu un timp de ecou de aproximativ $25 \mathrm{~s}$. Timpul de relaxare spin-spin $T_{\text {2eff }}$ a fost măsurat folosind o secvenţă de impuls CarrPurcell-Meiboom-Gill (CPMG) (Figura 1). 

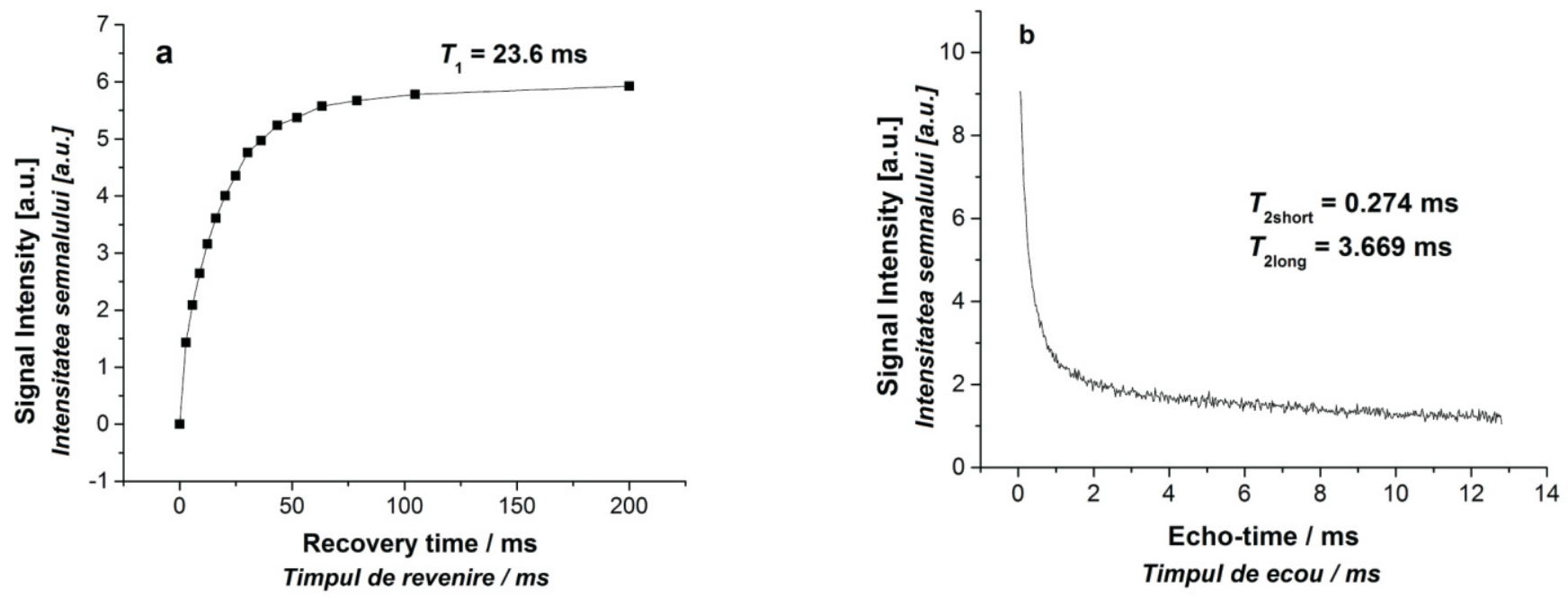

Figure 1. (a) Determination of $T_{1}$ spin-lattice relaxation time and (b) $T_{\text {2eff }}$ spin-spin relaxation time with the help of exponential functions for new quebracho leather

Figura 1. Ilustrarea modului de determinare a (a) timpului de relaxare spin-reţea $T_{1}$ şi a (b) timpului de relaxare spin-spin $T_{\text {2eff }} \mathrm{cu}$ ajutorul unor funcţii exponenţiale pentru pielea tăbăcită cu quebracho

\section{RESULTS AND DISCUSSION}

The structure of collagen was studied by various methods commensurate with different levels of its hierarchic organization, from molecules that successively pack into fibrils, to fibres and bundles (Figure 2) [12]. Microfibrils of collagen are composed of tropocollagen (which consists of three polypeptide chains, and each of them having a lefthanded helix conformation, twisted together into a right-handed coiled coil and forming a triple helix or "super helix") oriented in parallel bundles which results in structural anisotropy. Water molecules are bound to collagenous tissue and their motion is greatly restricted. The relaxation time is considered to be a measure of the mobility of water in the matrix, varying from about $10^{-6} \mathrm{~s}$ for frozen water to 2-3 s for liquid water [13]. Collagen deterioration affects the interactions between water and collagen molecules resulting in the variation of proton relaxation time values. To improve strength and durability, collagen may be cross-linked by chemical (e.g. tanning) or physical methods (e.g. ultraviolet irradiation and dehydrothermal treatments) [14, 15]. However, denaturation, the unwinding of the triple helical structure of the collagen molecule,

\section{REZULTATE ŞI DISCUTII}

Structura colagenului a fost studiată prin diverse metode adecvate fiecărui nivel de organizare ierarhică în parte, molecule, fibrile şi fibre. (Figura 2) [12]. Microfibrilele de colagen sunt compuse prin asocierea longitudinală şi transversală a moleculelor de tropocolagen (o moleculă constă din trei lanţuri polipeptidice, fiecare dintre acestea având o conformaţie elicoidală levogiră, răsucite împreună într-un „şnur" spiralat dextrogir numit triplu helix sau "super-helix") şi sunt orientate paralel, în fascicule, fapt care determină anizotropia specifică materialelor colagenice. Moleculele de apă sunt legate de structura colagenică şi mişcarea lor este, prin urmare, foarte limitată. Timpul de relaxare este considerat a fi o măsură a mobilităţii apei în matricea colagenică, acesta variind de la aproximativ $10^{-6} \mathrm{~s}$ în cazul apei în stare solidă până la 2-3 s pentru apa lichidă [13]. Deteriorarea colagenului afectează interacţiunile dintre moleculele de apă şi diversele niveluri structurale ale colagenului conducând la variaţia valorilor timpilor de relaxare ai protonilor. Pentru a-i îmbunătăţi rezistenţa şi durabilitatea, colagenul poate fi reticulat prin metode chimice (de exemplu, tăbăcire) sau fizice (de exemplu, iradiere cu raze ultraviolete şi tratamente de deshidratare termică) $[14,15]$. Cu toate acestea, denaturarea, adică pierderea structurii de triplu helix, reduce semnificativ 
markedly reduces its strength and increases the rate of biodegradation by fungal/bacterial enzymes [16, 17]. rezistenţa materialelor colagenice şi le creşte susceptibilitatea faţă de procesele de biodegradareinduse de enzimelefungiceşi bacteriene $[16,17]$.

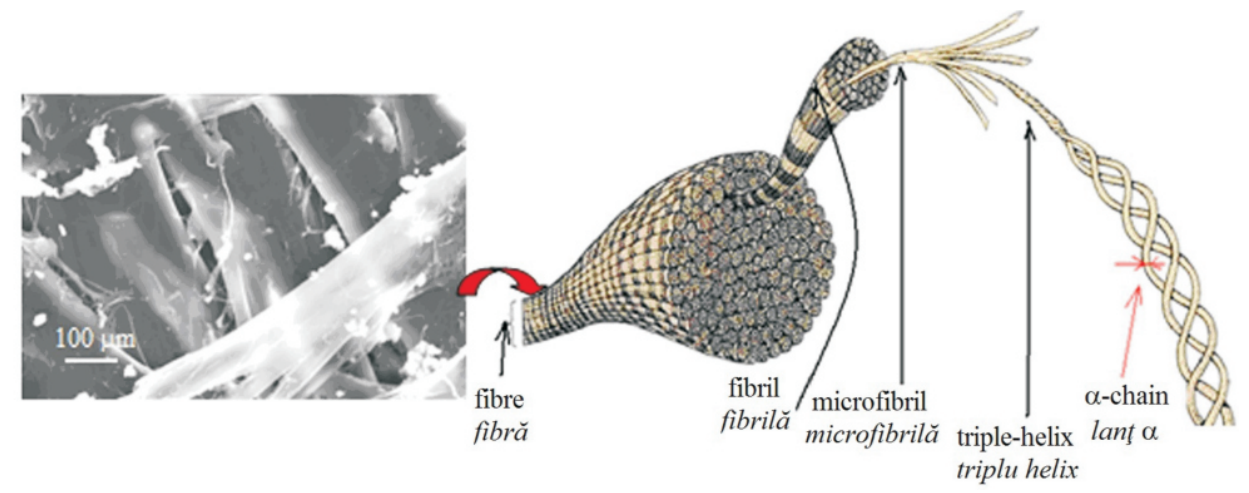

Figure 2. Hierarchical structure of collagen-based materials. Each collagen molecule is a right-handed triple-helix made of three left-handed -chains. Collagen molecules aggregate both in lateral and longitudinal directions to form fibrils. Multiple fibrils make up collagen fibres mainly through crosslinking.

This Figure is reproduced from the online version of Chimica e Industria [12].

Figura 2. Structura ierarhică a materialelor pe bază de colagen. Fiecare moleculă de colagen este o structură de tip triplu helix dextrogir, compusă din trei lanţuri polipeptidice de tip , levogire.

Moleculele de colagen se asociază atât în direcţie laterală, cât şi longitudinală pentru a forma fibrile. Mai multe fibrile compun fibrele de colagen, asociindu-se în principal prin reticulare.

Această figură este reprodusă din versiunea electronică a revistei Chimica e Industria [12].

\section{Dose-Dependent Effect of Gamma Radiation. Short- Term Modifications of Collagen-Water Interaction}

The recovery of longitudinal component of the water protons magnetisation has been characterised by a single $T_{1}$, whereas we have found that the $T_{2}$ exponential decay can be well described by two components: $T_{\text {2short }}$ and $T_{\text {2long }}$ (where $T_{\text {2short }}<T_{\text {2long }}$ ). Table 1 lists the $T_{1}, T_{\text {2short }}$ and $T_{2 \text { long }}$ values obtained for the quebracho leather samples exposed to increasing doses of gamma irradiation. Interactions of water molecules with complex systems like collagen-ligand (e.g. tannin matrix) are known to influence the structural ordering of both water and proteins. In a ternary system like collagen-tannin-water, alterations in the hydration structure of the macromolecular complex collagen-tannin are expected when structural modifications occur in collagen. The fluctuating cloud of water molecules surrounding polar residues in collagen can be affected by such modifications. In fact, the longitudinal $T_{1}$ relaxation time increases as the gamma irradiation dose increases (Figure 3 ). The increase is

\section{Efectul dozei de iradiere gamma. Modificări pe termen scurt ale interacţiunii colagen-apă}

Timpul de relaxare longitudinal, $T_{1}$, a fost obţinut prin fitarea datelor experimentale cu o funcţie exponenţială, iar timpul de relaxare transversal, $T_{2}$, a fost caracterizat prin două componente: $T_{\text {2short }}$ şi $T_{2 \text { long }}$ (unde $T_{2 \text { short }}<T_{\text {2long }}$ ), $\mathrm{cu}$ ajutorul altei funcţii cu două exponenţiale. În Tabelul 1 sunt prezentate valorile $T_{1}, T_{2 \text { short }}$ ş $T_{2 \text { long }}$ obţinute pentru probele de piele tăbăcită cu quebracho expuse la doze crescătoare de radiaţii gamma. Se ştie că interacţiunile dintre moleculele de apă cu sisteme complexe precum cele de tipul colagen-ligand (de exemplu, colagen-tanin) influenţează geometria structurală atât a apei, cât şi a proteinei. Într-un sistem ternar precum cel reprezentat de colagen-tanin-apă, sunt de aşteptat modificări în structura de hidratare a complexului macromolecular colagen-tanin ca urmare a modificărilor structurale ale moleculei de colagen. Norul fluctuant al moleculelor de apă din jurul reziduurilor polare din molecula de colagen poate fi afectat de aceste modificări. De fapt, s-a observat că timpul de relaxare longitudinal $T_{1}$ creşte pe măsură ce 
rather low up to a $50 \mathrm{kGy}$ dose (e.g. 10\%) and reaches $21 \%$ for the $100 \mathrm{kGy}$ dose (Table 1, column 2). The transverse relaxation times $T_{\text {2short }}$ and $T_{\text {2long }}$ have been attributed to the bound water and weakly bound water fractions [18, 19] respectively. It was previously showed that the values of $T_{\text {2short }}$ are more strongly influenced by the nature of the ligand bound to collagen [19]. It is worth mentioning that our recent results clearly demonstrate that $T_{2 \text { short }}$ depends on the tannin type, i.e. condensed or hydrolysable [20]. On the other hand, the results in Table 2 indicate that gamma irradiation treatment does not affect the $T_{2 \text { short }}$ value, whereas $T_{2 l o n g}$ values display a clear dependence on the gamma irradiation dose. The component $T_{\text {2long }}$ showed a maximum decrease of $16 \%$ for the $25 \mathrm{kGy}$ dose and then increased but without reaching the initial level of the not treated sample. Rodin and Nikerov [21] have attributed the short component $T_{\text {2short }}$ to the water fractions in microfibrils, while the long component $T_{2 \text { long }}$ was supposed to be associated with water molecules in the interfibrillar space. This later water fraction has more mobile molecules than that the microfibrillar water fraction being thus more susceptible to the variation of the hydration level, i.e. dehydration as a result of the cross-linking or swelling caused by a structural disorganization of the collagen macromolecules (e.g. polypeptide chain scissions) and the subsequent uptake of water [22, 23]. As a consequence, the $T_{\text {2long }}$ behaviour indicates an increase of cross-links up to $25 \mathrm{kGy}$ dose while polypeptide chain scission predominates at higher doses. creşte doza de iradiere (Figura 3). Creşterea este destul de limitată, aproximativ 10\%, până la o doză de 50 kGy, dar ajunge la 21\% la doza de $100 \mathrm{kGy}$ (Tabelul 1, coloana 2). Timpii de relaxare transversali $T_{\text {2short }}$ şi $T_{\text {2long }}$ măsuraţi în pielea tăbăcită cu quebracho au fost atribuiţi apei legate puternic, respectiv apei legate mai slab $[18,19]$. Studii precedente au arătat că valorile $T_{\text {2short }}$ sunt puternic influenţate de natura ligandului legat la colagen [19], fapt confirmat de rezultate obţinute recent care demonstrează în mod clar că $T_{\text {2short }}$ depinde de tipul de tanin, făcând posibilă distincţia între taninurile de tip condensat şi cele hidrolizabile [20]. Pe de altă parte, rezultatele din Tabelul 2 indică faptul că tratamentul cu radiaţii gamma nu afectează valoarea $T_{2 \text { short }}$ în timp ce valorile $T_{\text {2long }}$ indică o dependenţă clară de doza de iradiere. Componenta $T_{\text {2long }}$ prezintă o scădere maximă de $16 \%$ la o doză de 25 kGy, după care tendinţa se inversează şi $T_{\text {2long }}$ creşte, dar fără a atinge nivelul iniţial al probei netratate. Rodin şi Nikerov [21] au atribuit componenta scurtă $T_{\text {2short }}$ fracţiunilor de apă din microfibrile, în timp ce componenta lungă $T_{\text {2long }}$ a fost corelată cu moleculele de apă din spaţiul interfibrilar. Această ultimă fracţiune prezintă molecule cu o mobilitate mai mare decât cele din interiorul microfibrilelor şi este mai susceptibilă la variaţia nivelului de hidratare, de exemplu prin deshidratare în urma reticulării sau prin gonflare cauzată de destabilizarea structurii macromoleculare (de exemplu, prin scindări ale lanţului polipeptidic) care determină crearea mai multor situri de legare a apei $[22,23]$. În consecinţă, comportamentul $T_{2 \text { long }}$ indică prevalenţa proceselor de reticulare până la o doză de 25 kGy, în timp ce la doze mai mari predomină scindările lanţului polipeptidic.

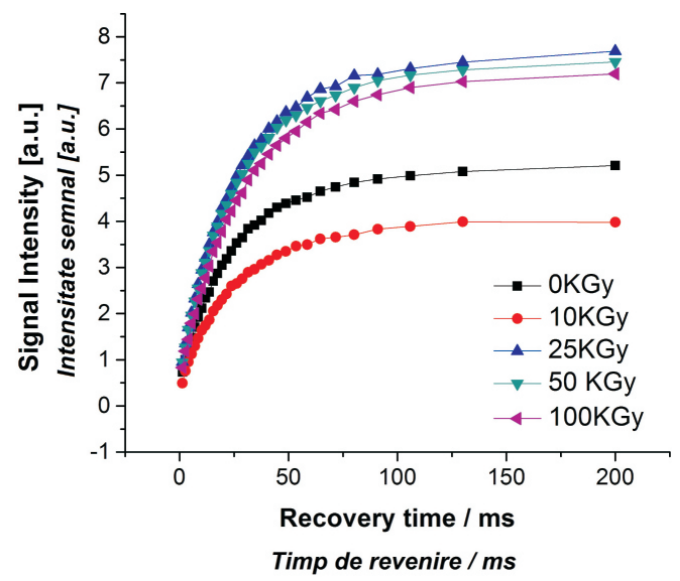

Figure 3. Variation of spin-lattice relaxation time $T_{1}$ as a function of gamma irradiation dose in quebracho tanned leather Figura 3. Variaţia timpului de relaxare spin-reţea $T_{1}$ în funcţie de doza de iradiere gamma în pielea tabacită cu quebracho 


\section{Dose-Dependent Effect of Gamma Radiation. Long-} Term Modifications of Collagen-Water Interaction

Table 2 lists the $T_{1}, T_{\text {2short }}$ and $T_{\text {2long }}$ values obtained for the mimosa leather samples exposed to increasing doses of gamma irradiation and then subjected to accelerated ageing at $40^{\circ} \mathrm{C}$ and weekly alternating $30 \%$ and $70 \% \mathrm{RH}$ for 12 weeks. The general trend observed for $T_{1}$ is represented by a rather limited increase which reaches its maximum (10\%) for the $25 \mathrm{kGy}$ dose (Table 2, column 2). The less influential dose is $10 \mathrm{kGy}$ with a $T_{1}$ variation of $3 \%$. Again, the short component $T_{2 \text { short }}$ of the spin-spin relaxation time is affected neither by the gamma irradiation long-term effect, nor by accelerated ageing treatment. On the contrary, the long component $T_{\text {2long }}$ displays a more complex behaviour: it slightly increases in the sample exposed to the lowest gamma irradiation dose, then decreases for $25 \mathrm{kGy}$ dose (e.g. $8 \%)$ and shows almost no variation for the highest doses, i.e. 50 and $100 \mathrm{kGy}$. The slight increase could be attributed to a slight hydration effect caused by the accelerated ageing treatment. This is very likely due to a less effective cross-linking induced by low irradiation doses. The significant decrease of $T_{210 n g}$ for the sample exposed to $25 \mathrm{kGy}$ confirms that the maximum concentration of cross-links is reached at this dose, whereas the polypeptide chain scission becomes the prevailing deterioration pattern for higher irradiation doses, i.e. 50 and 100 kGy, as also suggested by the increase of the longitudinal relaxation times $T_{1}$.

\section{Efectul dozei de iradiere gamma. Modificări pe termen lung ale interacţiunii colagen-apă}

Tabelul 2 prezintă valorile $T_{1}, T_{2 \text { short }}$ si $T_{\text {2long }}$ obţinute pentru probele de piele tăbăcită cu mimoză expuse la doze crescătoare de radiaţii gamma şi apoi supuse tratamentului de îmbătrânire accelerată. Tendinţa generală observată pentru $T_{1}$ este aceea a unei creşteri relativ limitate, care atinge maximul (10\%) la o doză de 25 kGy (Tabelul 2, coloana 2). Doza mai puţin influentă este cea de $10 \mathrm{kGy}$ care induce o variaţie a $T_{1}$ de numai $3 \%$. Şi în acest caz, componenta scurtă a timpului de relaxare spin-spin, $T_{2 s h o r t}$ nu este afectată tratamentul combinat de iradiere cu radiaţii gamma şi de îmbătrânire accelerată. Pe de altă parte, componenta lungă $T_{\text {2long }}$ prezintă un comportament complex: creşte uşor la proba expusă la cea mai mică doză de iradiere gamma, scade în cazul unei doze de 25 kGy (8\%) şi apoi creşte, rămânând aproape invariabilă la dozele maxime, respectiv 50 şi 100 kGy. Uşoara creştere iniţială ar putea fi datorată unui efect de hidratare uşoară cauzat de tratamentul de îmbătrânire accelerată, hidratare favorizată de reticulări mai puţin eficiente induse de dozele mici de iradiere. Scăderea mai semnificativă a $T_{2 \text { long }}$ in cazul probei expuse la $25 \mathrm{kGy}$ confirmă faptul că la această doză de iradiere se obţine concentraţia maximă de legături încrucişate. Creşterea timpilor de relaxare longitudinali $T_{1}$ sugerează un mecanism prevalent de deteriorare prin scindarea lanţului polipeptidic la doze de iradiere mai mari, adică 50 şi 100 kGy.

Table 1: Variation of $T_{1}, T_{\text {2short }}$ and $T_{\text {2long }}$ relaxation times of collagen in quebracho leather as a function of gamma irradiation dose after the irradiation treatment

Tabelul 1: Variaţia timpilor de relaxare $T_{1}, T_{\text {2short }}$ şi $T_{2 \text { long }}$ ai colagenului din pielea tăbăcită cu quebracho în funcţie de doza de radiaţii gamma

\begin{tabular}{c|c|c|c}
$\begin{array}{c}\text { Dose }(k G y) \\
\text { Doză }(k G y)\end{array}$ & $T_{1}(\mathrm{~ms})$ & $T_{2 \text { short }}(\mathrm{ms})$ & $T_{2 \text { long }}(\mathrm{ms})$ \\
\hline 0 & $23.06 \pm 0.35$ & $0.274 \pm 0.010$ & $3.669 \pm 0.236$ \\
\hline 10 & $24.25 \pm 0.13$ & $0.275 \pm 0.006$ & $3.291 \pm 0.144$ \\
\hline 25 & $25.14 \pm 0.90$ & $0.280 \pm 0.007$ & $3.066 \pm 0.225$ \\
\hline 50 & $25.25 \pm 0.07$ & $0.277 \pm 0.002$ & $3.441 \pm 0.249$ \\
\hline 100 & $27.95 \pm 0.78$ & $0.281 \pm 0.007$ & $3.423 \pm 0.444$ \\
\hline
\end{tabular}


Table 2: Variation of $T_{1}, T_{2 \text { short }}$ and $T_{2 \text { long }}$ relaxation times of collagen in mimosa leather as a function of gamma irradiation dose after the accelerated ageing treatment

( 12 weeks at $40^{\circ} \mathrm{C}$ and weekly alternating $30 \%$ and $70 \% \mathrm{RH}$ )

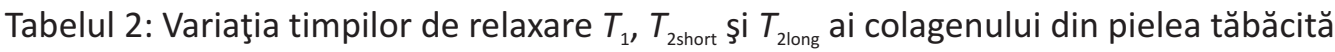
cu mimosa în funç̧ie de doza de iradiere gamma după îmbătrânire accelerată

(12 săptămâni la $40^{\circ} \mathrm{C}$ şi alternând săptămânal RH la $30 \%$ şi 70\%)

\begin{tabular}{c|c|c|c}
$\begin{array}{c}\text { Dose }(k G y) \\
\text { Doză }(k G y)\end{array}$ & $T_{1}(\mathrm{~ms})$ & $T_{\text {2short }}(\mathrm{ms})$ & $T_{\text {2long }}(\mathrm{ms})$ \\
\hline 0 & $17.20 \pm 0.57$ & $0.281 \pm 0.006$ & $2.327 \pm 0.109$ \\
\hline 10 & $17.84 \pm 1.09$ & $0.282 \pm 0.002$ & $2.373 \pm 0.015$ \\
\hline 25 & $19.04 \pm 0.77$ & $0.272 \pm 0.006$ & $2.138 \pm 0.161$ \\
\hline 50 & $18.61 \pm 0.59$ & $0.274 \pm 0.004$ & $2.321 \pm 0.100$ \\
\hline 100 & $18.17 \pm 0.06$ & $0.270 \pm 0.006$ & $2.375 \pm 0.900$ \\
\hline
\end{tabular}

\section{CONCLUSIONS}

New vegetable tanned leather was exposed to increasing doses of gamma irradiation ranging from 10 to $100 \mathrm{kGy}$. The dose-dependent effect of gamma irradiation on collagen in leather was investigated by unilateral NMR using a portable NMR MOUSE equipment. Examination of irradiated samples after the treatment revealed variations of both spin-lattice $\left(T_{1}\right)$ and spin-spin $\left(T_{2}\right)$ proton relaxation times: $T_{1}$ monotonously increased with increasing of dose, while $T_{\text {2long }}$ showed a minimum for the $25 \mathrm{kGy}$ irradiation dose. To evaluate the long-term effect of gamma irradiation, the irradiated samples were further exposed to accelerate ageing at $40^{\circ} \mathrm{C}$ and weekly alternate $30 \%$ and $75 \%$ relative humidity ( $\mathrm{RH}$ ) for 12 weeks. The synergistic action of temperature and relative humidity caused distinct variations of both $T_{1}$ and $T_{\text {2long }}$ relaxation times. $T_{\text {2long }}$ showed a minimum at 25 $\mathrm{kGy}$ and a maximum at $100 \mathrm{kGy}$ suggesting distinct modifications within the collagen fibril structure by cross-linking and hence dehydration at $25 \mathrm{kGy}$, and polypeptide chain destabilisation resulting in a very likely increasing of the swelling capacity, at higher doses. Moreover, $T_{1}$ displayed an increase up to $25 \mathrm{kGy}$ dose and then slightly decreased. These results suggest that a critical level of

\section{CONCLUZII}

Pielea nouă tăbăcită vegetal a fost expusă la doze crescătoare de radiaţii gamma: 10, 25, 50 si 100 kGy. Efectul dozei de radiaţii gamma asupra colagenului din piele a fost investigat prin RMN unilaterală utilizând un dispozitiv portabil NMR-MOUSE. Examinarea probelor iradiate imediat după tratament a relevat variaţii ale timpilor de relaxare ai protonilor spin-reţea $\left(T_{1}\right)$ şi spin-spin $\left(T_{2}\right): T_{1}$ a crescut monoton odată cu creşterea dozei, în timp ce $T_{\text {2long }}$ a prezentat o valoare minimă la doza de 25 kGy. Pentru a evalua efectul pe termen lung al radiaţiilor gamma, probele iradiate au fost expuse în continuare la îmbătrânire accelerată la $40^{\circ} \mathrm{C}$ cu alternarea săptămânală a umidităţii relative (UR) la $30 \%$ şi la $75 \%$, timp de 12 săptămâni. Acţiunea sinergică a temperaturii şi a umidităţii relative a determinat variaţii ale timpilor de relaxare $T_{1}$ şi $T_{\text {2long }}$. $T_{\text {2long }}$ a prezentat o valoare minimă la 25 kGy şi una maximă la 100 kGy sugerând modificări distincte în structura fibrilelor de colagen, şi anume reticulare şi, implicit, deshidratare la 25 kGy, şi scindarea lanţului polipeptidic (care a dus la o creştere a capacităţii de gonflare) la doze mai mari. Mai mult decât atât, $T_{1}$ a prezentat un comportament dual, crescând până la doza de 25 kGy şi apoi scăzând uşor. Aceste rezultate sugerează cu mare probabilitate un nivel critic de iradiere corespunzător 
structural modifications is reached at $25 \mathrm{kGy}$ irradiation dose.

\section{Acknowledgments}

The authors gratefully acknowledge the national project PN 091003 13, "Study of CollagenBased Artefact Deterioration Using Nuclear Magnetic Resonance Techniques and Equipment", national project TEXLECONS 213/2012, "Improvement of Occupational Environment Quality in Cultural Heritage Deposits. Validation of Gamma Irradiation Treatment of Textile and Leather Cultural Goods", and the Sectorial Operational Programme Human Resources Development 2007-2013 POSDRU/159/1.5/S/132395. dozei de 25 kGy, nivel la care se înregistrează modificările structurale cele mai evidente.

\section{Mulţumiri}

Această lucrare a fost realizată în cadrul proiectului naţional PN 09100313 „Studiul deteriorării artefactelor pe bază de colagen utilizând tehnici şi echipamente de rezonanţă magnetică nucleară", a programului Parteneriate derulat cu sprijinul MECUEFISCDI, proiectul nr. 213/2012 „Îmbunătăţirea calităţii mediului de lucru în depozitele de patrimoniu cultural. Validarea tratamentului bunurilor culturale textile şi din piele cu radiaţii gamma" şi a Programului Sectorial Operaţional Dezvoltarea Resurselor Umane 2007-2013 POSDRU/159/1.5/S/132395.

\section{REFERENCES}

1. Covington, A.D., Modern tanning chemistry, Chem Soc Rev, 1997, 26, 111-26.

2. Zywicki, B., Reemtsma, T., Jekel, M., J Chromatogr A 970, 2002, 191-200.

3. Da Silva Aquino, K.A., Intech Journals, www.intechopen.com.

4. Maslennikova, A., Kochueva, M., Ignatieva, N., Vitkin, A., Zakharkina, O., Kamensky, V., Sergeeva, E., Kiseleva, E., Bagratashvili, V., Int J Radiat Biol, 2015, 91, 3, 240-247.

5. Leontiou, I., Matthopoulos, D.P., Tzaphlidou, M., Glaros, D., Micron, 1993, 24, 13-16.

6. Ohan, M.P., Dunn, M.G., Wiley Periodicals, 2003.

7. Nunes, I., Mesquita, N., CaboVerde, S., Trigo, M., Ferreira, A., Carolino, M.M., Portugal, A., Botelho, M.L., Radiat Phys Chem, 2012, 81, 1943-1946.

8. Badea, E., Miu, L., Budrugeac, P., Giurginca, M., Mašić, A., Badea, N., Della Gatta, G., J Therm Anal Calorim, 2008, 91, 17-27.

9. Sendrea, C., Badea, E., Miu, L., Ignat, M., lovu, H., Proceedings of The $5^{\text {th }}$ International Conference on Advanced Materials and Systems (ICAMS), Bucharest, 23-25 October 2014, 555-560.

10. Miu, L., Brătulescu, V., Gaidău, C., Bocu, V., Niculescu, O., Process for making natural leather for patrimony book binding, Romanian patent no. 122098, 2008.

11. Oligschlaeger, D., Gloeggler, S., Watzlaw, J., Brendel, K., Jaschtschuk, D., Colell, J., Zia, W., Vossel, M., Schnakenberg, U., Bluemich, B., Appl Magn Reson, 2015, 46, 181-202.

12. Della Gatta, G., Badea, E., Saczuk, M., Odlyha, M., Larsen, R., Chimica e Industria, 2010, 4, 106-111.

13. Lambert, J.B., Graham, E., Smith, M.T., Frye, J.S., Ancient Mesoamerica, 1994, 5, 55-60.

14. Cheung, D., Perelman, N., Tong, D., Nimni, M., J Biomed Mater Res, 1990, 24, 581-589.

15. Grant, R.A., Cox, R.W., Kent, C.M., J Anat, 1973, 115, 29-43.

16. Ohan, M.P., Weadock, K.S., Dunn, M.G., J Biomed Mater Res, 2002, 60, 384-391.

17. Chirila, C., Deselnicu, V., Crudu, M., Comparative Study Regarding the Resistance of Wet-White and Wet-Blue Leather to the Growth of Fungi, Revista de Pielarie Incaltaminte (Leather and Footwear Journal), 2014, 14, 2, 107 120. 
18. Grigera, J.R, Berendsen, H.J.C., Biopolymers, 1979, 18, 47-57.

19. Nishad Fathimaa, N., Baiasc, M., Bluemich,B., Ramasami, T., Int J Biol Macromol, 2010, 47, 590-596.

20. Badea, E., Şendrea, C., Carşote, C., Adams, A., Bluemich, B., lovu, H., Microchem J, 2015 (in press).

21. Victor Rodin, V., Victor Nikerov, A., Tissue Eng, 2014, 3, 47-61.

22. Badea, E. Della Gatta, G., Usacheva,T., Polym. Degrad. Stab., 2012, 97, 346-353.

23. Badea, E., Usacheva, T., Della Gatta, G., Rossiiskii Khimicheskii Zhurnal - Zhurnal Rossiiskogo Khimicheskogo Obshchestva im. D.I. Mendeleeva (Russian Chemistry Journal), 2015, 59, 1, 28-41.

Article received/Data primirii articolului: 29.07.2015

Accepted/Acceptat la data: 25.09.2015 